\title{
Article \\ Heat Generation and Temperature Control during Bone Drilling for Orthodontic Mini-Implants: An In Vitro Study
}

\author{
Ibrahim Barrak ${ }^{1, *}$, Gábor Braunitzer ${ }^{2}$, József Piffkó ${ }^{1}$ and Emil Segatto ${ }^{1}$ \\ 1 Craniofacial Unit, Department of Oral and Maxillofacial Surgery, Faculty of Medicine, University of Szeged, \\ 6725 Szeged, Hungary; piffkojozsef@gmail.com (J.P.); dr@segatto.hu (E.S.) \\ 2 Dicomlab Dental Ltd., 6726 Szeged, Hungary; gabor.braunitzer@dicomlab.com \\ * Correspondence: barrakibrahim@gmail.com; Tel.: +36-70-611-5247
}

check for updates

Citation: Barrak, I.; Braunitzer, G.; Piffkó, J.; Segatto, E. Heat Generation and Temperature Control during Bone Drilling for Orthodontic Mini-Implants: An In Vitro Study. Appl. Sci. 2021, 11, 7689. https:// doi.org/10.3390/app11167689

Academic Editor: Mitsuru Motoyoshi

Received: 29 June 2021

Accepted: 14 August 2021

Published: 21 August 2021

Publisher's Note: MDPI stays neutral with regard to jurisdictional claims in published maps and institutional affiliations.

Copyright: (c) 2021 by the authors. Licensee MDPI, Basel, Switzerland. This article is an open access article distributed under the terms and conditions of the Creative Commons Attribution (CC BY) license (https:/ / creativecommons.org/licenses/by/ $4.0 /)$.

\begin{abstract}
Background: The purpose of our in vitro study was to evaluate the impact of different irrigation fluid temperatures in combination with different drilling speeds on intraosseous temperature changes during mini-implant site preparation. Methods: Porcine ribs were used as bone specimens. Grouping determinants were as follows: irrigation fluid temperature $\left(10\right.$ and $\left.20^{\circ} \mathrm{C}\right)$ and drilling speed $(200,600,900$, and $1200 \mathrm{RPM})$. The axial load was controlled at $2.0 \mathrm{~kg}$. Temperature measurements were conducted using K-type thermocouples. Results: Extreme increments were observed only in the unirrigated groups. Irrigation invariably made a significant difference within groups defined by the same drilling speed. The comparison of the different temperature irrigation fluids $\left(10\right.$ and $\left.20^{\circ} \mathrm{C}\right)$ in combination with the same drilling speed $(200,600,900$, or $1200 \mathrm{rpm})$ resulted in a statistically significant difference between the two different temperatures, whereas the use of irrigation fluid at a controlled room temperature of $20{ }^{\circ} \mathrm{C}$ showed significantly higher temperature changes. Conclusions: Based on the results of the study, we conclude that irrigation while preparing a pilot hole for a self-tapping orthodontic miniscrew is of utmost importance, even at low drilling speeds. The temperature of the cooling fluid does influence local temperature elevation to a significant extent.
\end{abstract}

Keywords: orthodontic screw; mini-implant; pre-drilling; heat production; temperature; irrigation; cooled irrigation; safety; bone drilling

\section{Introduction}

Anchorage in the orthodontic field can be defined as a resistance to unwanted tooth movement [1]. To achieve such resistance, anchorage units are utilized. A stable anchorage unit is a crucial element of successful orthodontic treatment. To achieve the required anchorage, dental implants, palatal implants, mini-plates, or mini-implants have been used [2-4]. These devices are attached to the basal bone or the alveolar process of the maxilla or the mandible; therefore, they provide skeletal anchorage. Given that they are in place only for the duration of the orthodontic treatment, they are usually referred to as temporary anchorage devices (TADs). In 1997, Kanomi introduced mini-implants that were specifically developed to provide stable anchorage during orthodontic treatment [5]. Because of their many advantages (versatility, independence of patient adherence, minimal surgical invasiveness, low morbidity, relative affordability, and good patient acceptance), mini-implants have become especially popular among orthodontists [6-8]. Despite their short length and small diameter, mini-implants offer stable anchorage for different types of tooth movement, including retraction, distalization, mesialization, and intrusion $[9,10]$. In terms of insertion, two main kinds of mini-implants may be distinguished: self-drilling, which does not require a pilot hole, and non-self-drilling (i.e., self-tapping), which requires the drilling of a pilot hole before the implant placement. Complications of this approach to anchorage include injury of the roots of the neighboring teeth, implant loosening, and even implant fracture [11]. Uemura and his colleagues concluded that mini-implant 
stability could be influenced by implant diameter, inflammation of the peri-implant tissues, cortical bone thickness, and high mandibular plane angle [12]. It was also found that temperature elevation at the level of the cortical bone and higher torque during insertion may result in an early implant loss $[9,13,14]$. Some studies reported lower success rates with mandibular mini-implants $[11,13,15-17]$ due to microcracks caused by over-torquing in thick and hard bone [9] and the consequent excessive heat production. Tachibana and co-workers achieved optimal insertion torque by pre-drilling, and this way they managed to avoid osteonecrosis [9]. In contrast, Gurdán et al. reported that pre-drilling for $1.6 \mathrm{~mm}$ self-drilling mini-implants with a $1 \mathrm{~mm}$ diameter pilot drill did not decrease intraosseous temperatures when the mini-implant was placed into a model mandible [18]. Matsuoka et al. measured the heat production during the placement of self-drilling mini-implants without the preparation of the pilot hole, and they found that self-drilling at speeds higher than $150 \mathrm{rpm}$ causes thermal damage [14]. Uemura and co-workers concluded that the ratio of the diameter of the pilot hole and the mini-implant is an important factor in implant stability [12]. Despite the beneficial advantages of adequate predrilling on implant stability, the drilling procedure itself can have effects on intraosseous temperature during mini-implant placement. During the rotary cutting of the drills, the generated heat may accumulate locally, especially at the level of the denser cortical bone, which can eventually lead to necrosis [19]. The characteristics of the bone (whether the cortex of the mandible or the cortical bone of the anterior palate) can also lead to an increased risk of overheating during drilling. It is amply documented in the literature that osteonecrosis occurs when the intraosseous temperature rises to $47^{\circ} \mathrm{C}[16,20]$. To our knowledge, intraosseous heat generation during pre-drilling of a pilot hole at different drilling speeds in combination with irrigation fluids of different temperature has not been previously investigated in the literature. The purpose of our in vitro study was to evaluate the impact of different irrigation fluid temperatures in combination with different drilling speeds on intraosseous temperature changes during mini-implant site preparation.

\section{Materials and Methods}

\subsection{Bone Model}

Porcine ribs were used for the experiments because of their favorable anatomical and thermophysical characteristics [18,21,22]. The study conducted by Kim and his colleagues [23] concluded that cortical bone thickness falls in a range of approximately 1.14-1.49 mm for the human maxilla at the sites of orthodontic implant placement. The specimens selected were in the above-mentioned range between 1.2 and $1.5 \mathrm{~mm}$ (as can be seen in Figure 1), which is also a widely used value in the literature [9].

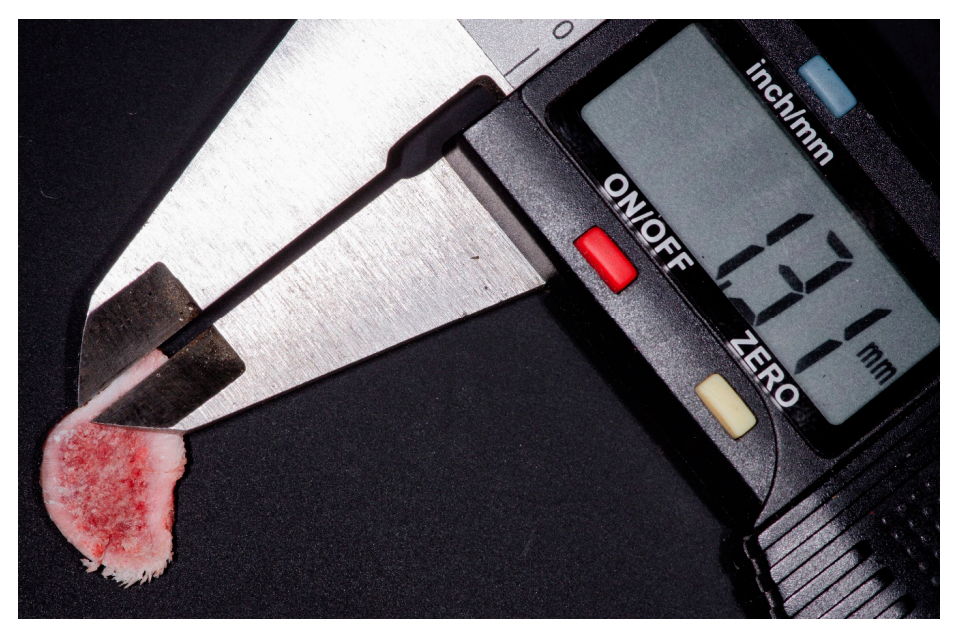

Figure 1. Porcine rib model used for the in vitro experiment with a cortical bone thickness of $1.31 \mathrm{~mm}$. 
Sener et al. [24] proved in their study that the increase in intraosseous temperature elevation was greater in the cortical layer of the bone in comparison to the deeper parts of the drilled cavity. This finding has also been confirmed by other studies [25,26]. Bones were taken from the same animal, and the animals were not killed for the sake of the experiments. The specimens were all stored at a temperature of $-10{ }^{\circ} \mathrm{C}$ in normal saline when not used as it is suggested by Sedlin and Hirsch [27].

\subsection{Setup}

Drillings were performed in accordance with the manual of the Benefit orthodontic implant system (PSM Medical Solutions, Tuttlingen, Germany) with a diameter of $1.4 \mathrm{~mm}$ as can be seen in Figure 2.

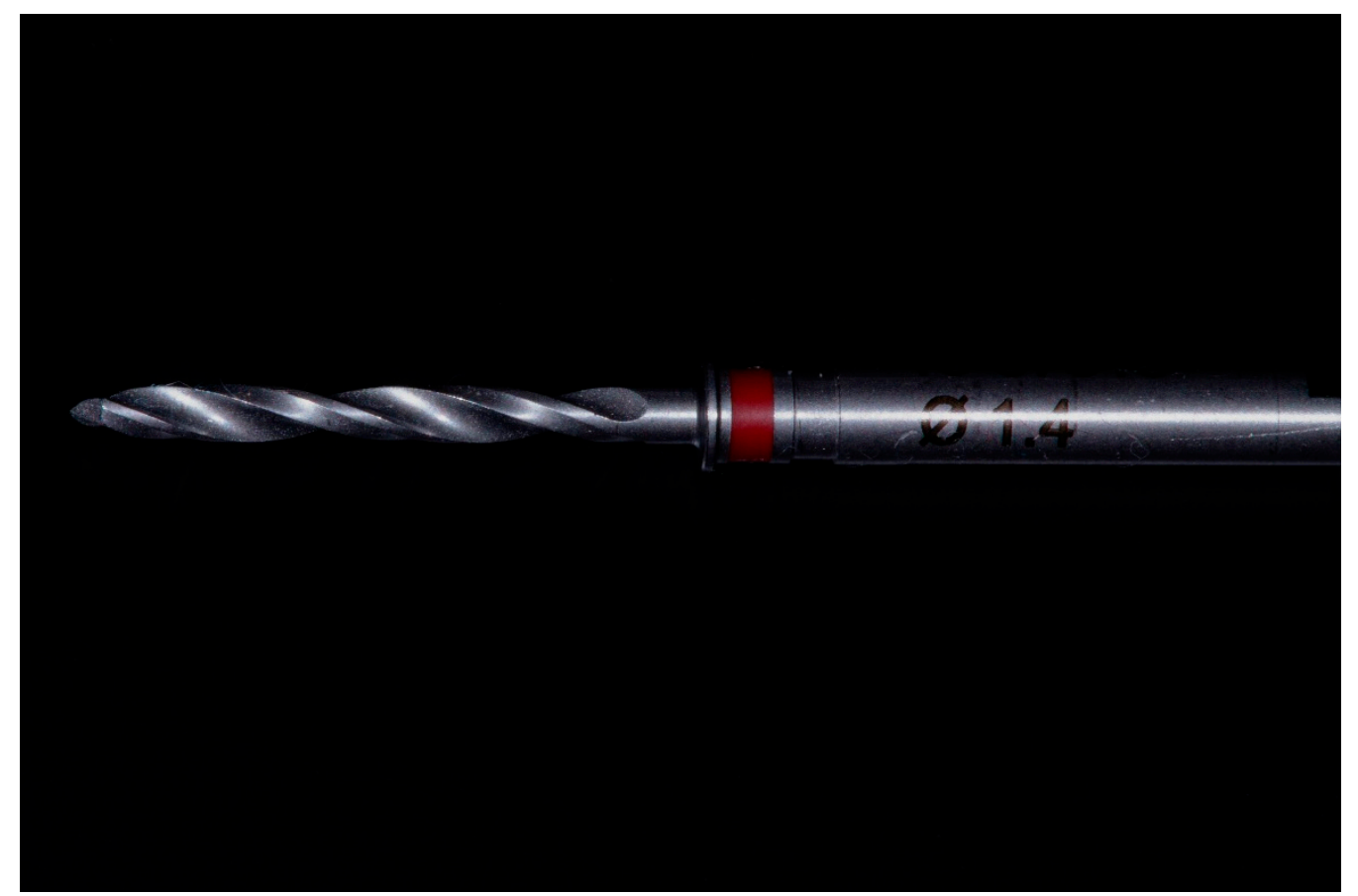

Figure 2. $1.4 \mathrm{~mm}$ diameter drill used for the investigation.

Osteotomies were carried out at the drilling speeds of 200, 600, 900, and $1200 \mathrm{rpm}$; all of these mentioned were used in the literature $[18,28,29]$. We also compared the use of irrigation fluids at different temperatures $\left(20\right.$ and $\left.10{ }^{\circ} \mathrm{C}\right)$ with no irrigation. A total of 40 drillings were performed in each of the 12 groups. Entry points for the freehand groups were marked on the surface of the bone specimens.

Studies suggest that the maximum temperature increment can be observed in the cortical layer of the bone [24-26]. Therefore, we performed temperature measurements in the cortical layer of the bone. K-type thermocouples were used for temperature measurements with a connected measurement device (HoldPeak 885A, HoldPeak; Zhuhai, Guangdong, China). The thermocouples were consistently placed into a cavity prepared with a $1.5 \mathrm{~mm}$ diameter implant drill and a depth control of $1.2 \mathrm{~mm}$; therefore, we could ensure that the depth of the cavity never exceeded the cortical layer. Measurement cavities were positioned at a $1.00 \mathrm{~mm}$ horizontal distance from the $1.4 \mathrm{~mm}$ drilling canal. The thermocouple was placed touching the lateral bony wall of the cavity being closer to the implant bed to be drilled, followed by tight filling with bone chips derived from rib specimens of the same animal, and the hole was thoroughly sealed with plasticine to maintain adequate insulation (Figure 3). 


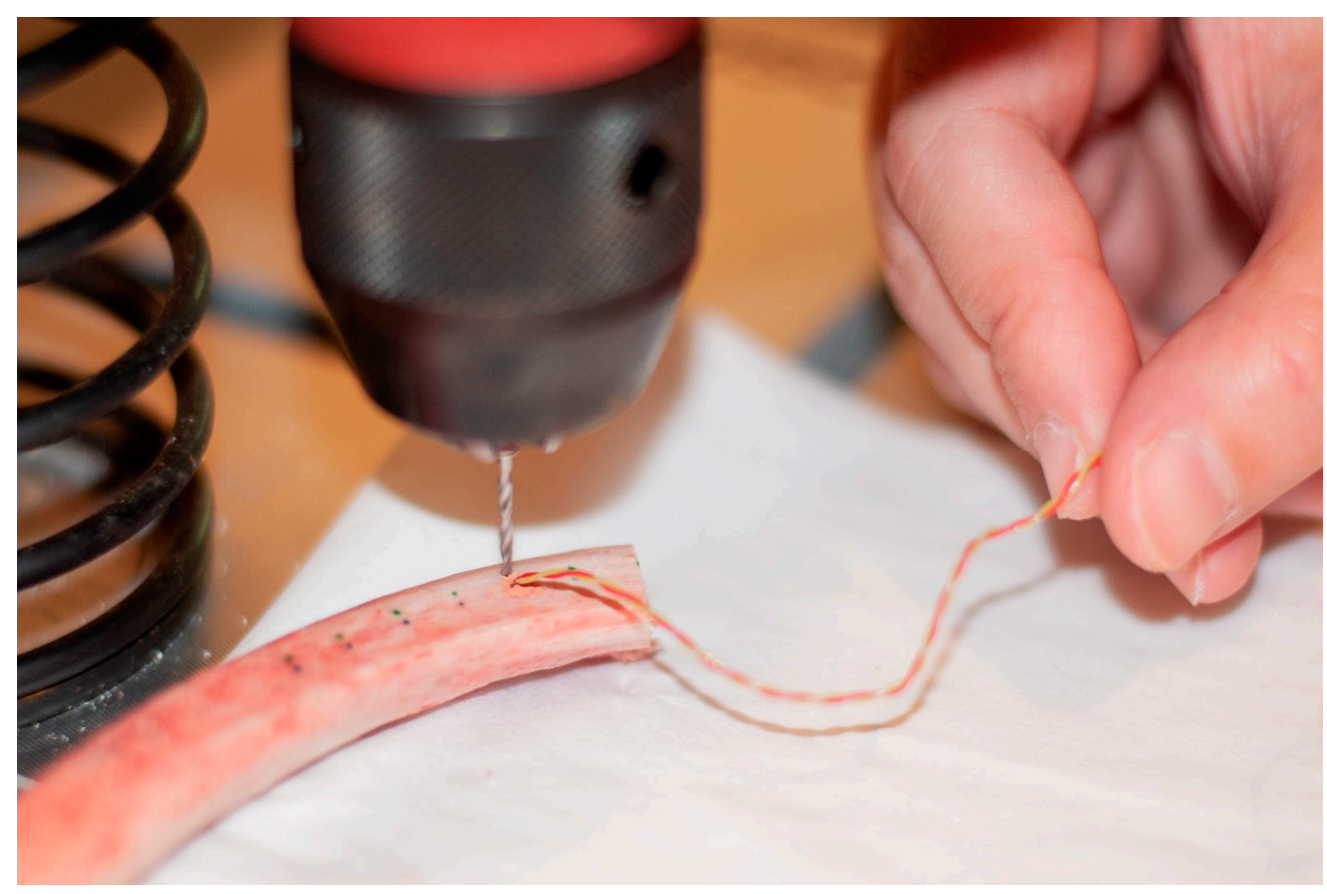

Figure 3. A close-up of the experimental setting.

A constant axial load of $2.0 \mathrm{~kg}$ was used, as it can be considered as a low hand pressure, and it is extensively used in the literature, as it can be seen in reviews also concerning the topic [21,30-32]. The constant load was achieved by placing a weight on top of the drilling apparatus and then manipulating the resistance in a way that the load exerted by the tip of the drill was $2.0 \mathrm{~kg}$. A bench drill with an adjustable drilling speed was used for the experiments (Bosch PBD 40; Bosch, Stuttgart, Germany). The specimens were heated up to a temperature of $37^{\circ} \mathrm{C}$. Drillings with temperature measurement were only executed if the baseline temperature of the bone was between 35 and $37^{\circ} \mathrm{C}$. A single drilling lasted 5-10 s.

A constantly controlled external irrigation was provided by a widely known, accepted, and used surgical unit (INTRAsurg 300, KaVo Dental GmbH, Biberach/Riß, Germany), and the standard cannula of another system was used (W\&H). The cannula was safely and precisely attached to the drilling machine, and it was directed toward the drill bit. The flow rate was $100 \mathrm{~mL} / \mathrm{min}$ as recommended in the literature [33-36]. The temperature of the irrigation fluid was either $20 \pm 1{ }^{\circ} \mathrm{C}$ or $10 \pm 1{ }^{\circ} \mathrm{C}$. The temperature of the irrigation fluid was always checked with an infrared thermometer before every measurement.

The full setup can be seen in Figure 4. All the drilling procedures were conducted in the same air-conditioned room, where the temperature was controlled within the range of $20 \pm 1{ }^{\circ} \mathrm{C}$.

\subsection{Collection of Data and Statistical Analysis}

Baseline and peak temperatures were collected to one decimal point in a spreadsheet file in Microsoft Excel 2013 15.0 (Microsoft Corporation, Redmond, WA, USA). Temperature elevations were calculated as peak temperature minus baseline temperature to one decimal point using the spreadsheet. The data were analyzed in SPSS 23.0 (Armonk, NY, USA, IBM). The normality of distributions was tested with the Shapiro-Wilk test. As non-normal distributions were observed, Kruskal-Wallis ANOVA was used. 


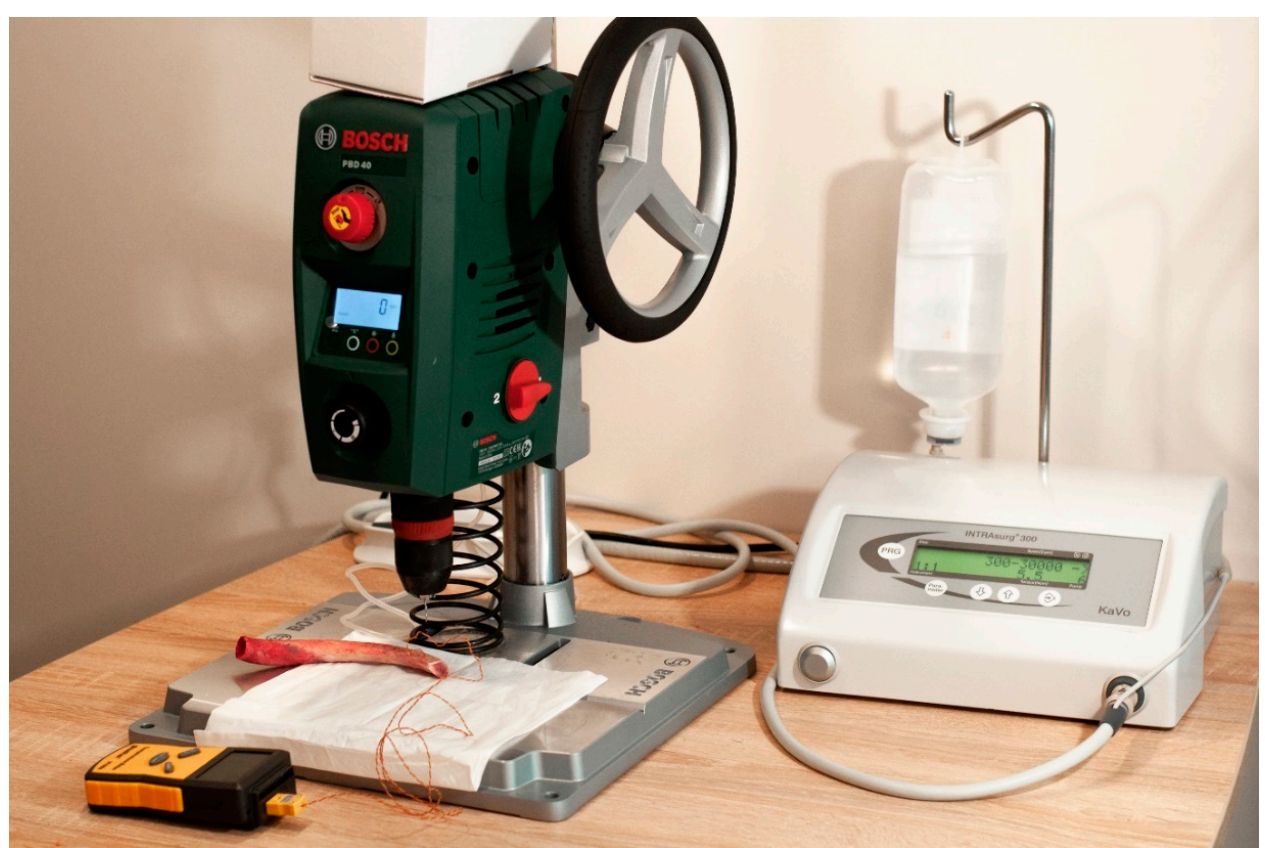

Figure 4. The study setting, including the bench drill, and the irrigation system (provided by the surgical unit).

\section{Results}

The descriptive statistics of the measured thermal changes are given in Table 1.

Table 1. Mean temperature rises, maximum and minimum of temperature rises, groups divided by different drilling speeds, and temperature of the irrigation fluid.

\begin{tabular}{|c|c|c|c|c|c|c|c|}
\hline $\begin{array}{l}\text { Grouping } \\
\text { Number }\end{array}$ & $\begin{array}{c}\text { Drilling } \\
\text { Speed (rpm) }\end{array}$ & $\begin{array}{l}\text { Temperature } \\
\text { of Irrigation } \\
\text { Fluid }\left({ }^{\circ} \mathrm{C}\right)\end{array}$ & $\begin{array}{l}\text { Number of } \\
\text { Drillings }\end{array}$ & $\begin{array}{c}\text { Mean (SD) } \\
\text { Temperature } \\
\text { Rise }\left({ }^{\circ} \mathrm{C}\right)\end{array}$ & $\begin{array}{c}\text { Maximum } \\
\text { Temperature } \\
\text { Rise }\left({ }^{\circ} \mathrm{C}\right)\end{array}$ & $\begin{array}{c}\text { Minimum } \\
\text { Temperature } \\
\text { Rise }\left({ }^{\circ} \mathrm{C}\right)\end{array}$ & $\begin{array}{c}\text { Median } \\
\text { Temperature } \\
\text { Value }\left({ }^{\circ} \mathrm{C}\right)\end{array}$ \\
\hline 1 & 200 & 10 & 40 & $-2.45(0.57)$ & -1.30 & -3.50 & -2.50 \\
\hline 2 & 200 & 20 & 40 & $0.05(0.07)$ & 0.20 & 0.00 & 0.00 \\
\hline 3 & 200 & no irrigation & 40 & $2.22(0.71)$ & 3.80 & 1.20 & 2.10 \\
\hline 4 & 600 & 10 & 40 & $-1.76(0.35)$ & -1.00 & -2.80 & -1.80 \\
\hline 5 & 600 & 20 & 40 & $1.02(0.33)$ & 1.30 & 0.00 & 1.20 \\
\hline 6 & 600 & no irrigation & 40 & $3.75(0.97)$ & 6.10 & 2.00 & 3.75 \\
\hline 7 & 900 & 10 & 40 & $-1.02(0.38)$ & 0.20 & -1.30 & -1.15 \\
\hline 8 & 900 & 20 & 40 & $1.48(0.56)$ & 2.60 & 0.50 & 1.30 \\
\hline 9 & 900 & no irrigation & 40 & $5.92(1.14)$ & 9.50 & 4.40 & 5.90 \\
\hline 10 & 1200 & 10 & 40 & $-0.18(0.23)$ & 1.30 & 0.00 & 0.10 \\
\hline 11 & 1200 & 20 & 40 & $1.86(0.65)$ & 3.40 & 1.20 & 1.70 \\
\hline 12 & 1200 & no irrigation & 40 & $7.76(1.59)$ & 11.50 & 4.70 & 7.45 \\
\hline
\end{tabular}

SD: Standard deviation.

Almost all pairwise comparisons indicated significant difference at $p<0.05$; the exceptions are given in Table 2.

In three groups, the measured temperature increment was $>5^{\circ} \mathrm{C}$ (no irrigation at 600 , 900 , and $1200 \mathrm{rpm}$ ). In one group, the temperature increment was $\geq 10^{\circ} \mathrm{C}$ (no irrigation at 900 and $1200 \mathrm{rpm}$ ). Thus, extreme increments were observed only in the unirrigated groups. Irrigation invariably made a significant difference within groups defined by the same drilling speed. The use of a $20^{\circ} \mathrm{C}$ irrigation fluid resulted in a lower temperature increment, which remained in the safe zone throughout the use of every drilling speed (200, $600,900$, and $1200 \mathrm{rpm})$. In all of the groups with $10^{\circ} \mathrm{C}$ external irrigation, the measured temperature changes were negative in comparison to the baseline cortical intraosseous 
temperature, despite the drilling procedure. This might be the result of the cooling effect of the irrigation fluid being more pronounced than the heat-producing effect of the drilling. The comparison of the different temperature irrigation fluids $\left(10\right.$ and $\left.20^{\circ} \mathrm{C}\right)$ in combination with the same drilling speed $(200,600,900$, or $1200 \mathrm{rpm})$ resulted in a statistically significant difference between the two different temperatures, whereas the use of irrigation fluid at a controlled room temperature of $20^{\circ} \mathrm{C}$ showed significantly higher temperature changes.

A graphical summary of the results is given in Figure 5.

Table 2. The non-significant differences can be seen after the pairwise comparison.

\begin{tabular}{cccc}
\hline Grouping Number & Drilling Speed (rpm) & $\begin{array}{c}\text { Temperature of } \\
\text { Irrigation Fluid }\left({ }^{\circ} \mathbf{C}\right)\end{array}$ & $\begin{array}{c}\text { No significant } \\
\text { Difference Could Be } \\
\text { Observed } \boldsymbol{p}<\mathbf{0 . 0 5}\end{array}$ \\
\hline 1 & 200 & 10 & 4 \\
2 & 200 & 20 & 7,10 \\
3 & 200 & no irrigation & $6,8,11$ \\
4 & 600 & 10 & 1,7 \\
5 & 600 & 20 & 8,10 \\
6 & 600 & no irrigation & 3,9 \\
7 & 900 & 10 & 2,4 \\
8 & 900 & 20 & $3,5,11,12$ \\
9 & 900 & no irrigation & 6,12 \\
10 & 1200 & 10 & 2,5 \\
11 & 1200 & 20 & 3,8 \\
12 & 1200 & no irrigation & 8,9 \\
\hline
\end{tabular}

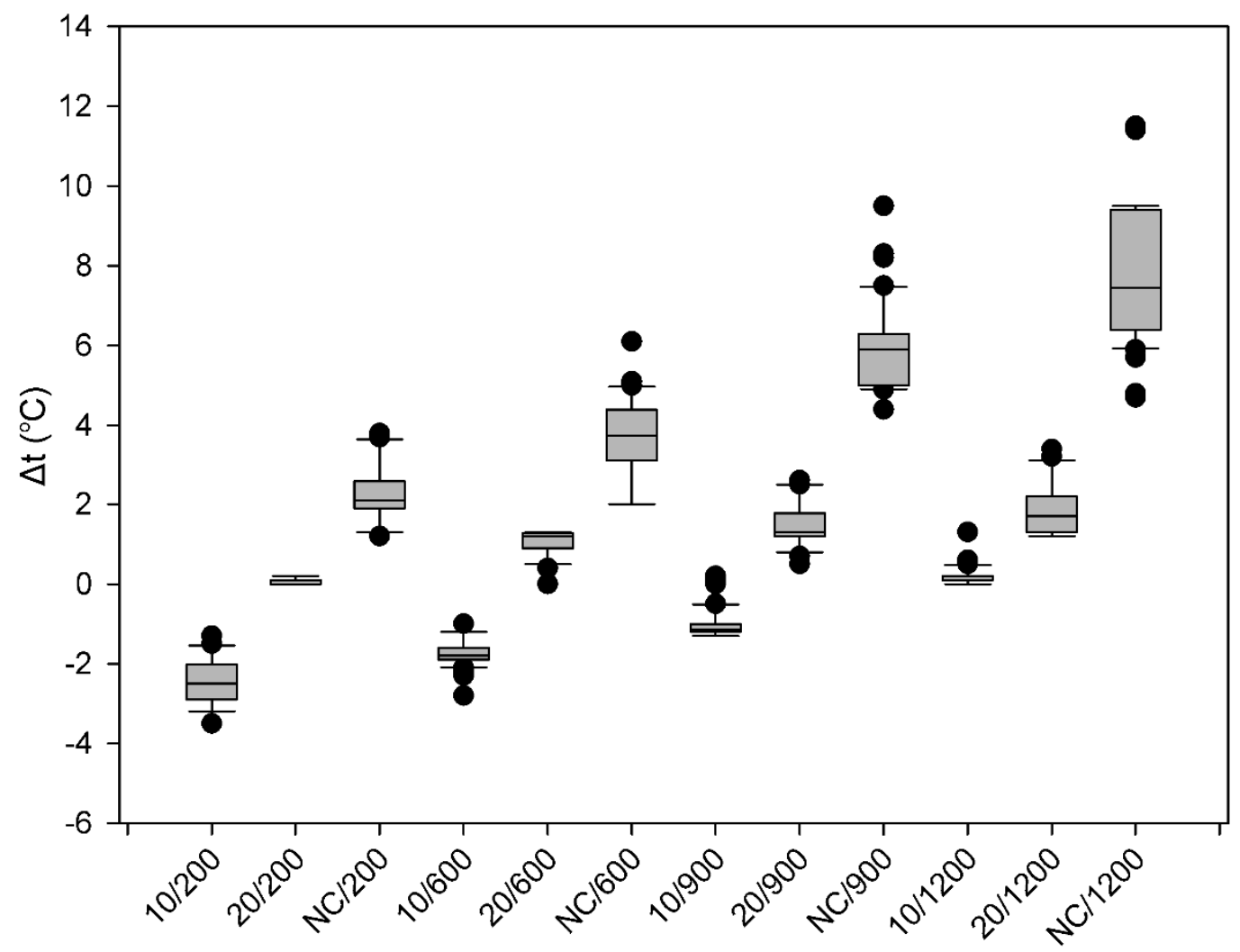

Figure 5. Temperature changes across the study groups. The lower margin of the boxes shows the 25th percentile, the line within the boxes marks the median, and the upper margin of the boxes indicates the 75th percentile. The error bars (whiskers) above and below the boxes indicate the 90th and 10th percentiles. The black dots represent the outliers. Labels of the $X$-axis: temperature of cooling fluid $\left({ }^{\circ} \mathrm{C}\right) / \mathrm{rpm}$; NC: no cooling. 


\section{Discussion}

Anchorage control is a key factor of success in clinical orthodontics [11]. According to the literature, miniscrew failure can be traced back to multiple factors, including bone density, the thickness of the cortical bone, screw length, diameter and design (shape of the screw thread), insertion angle and torque, the type of the miniscrew (self-drilling or self-tapping), the amount and direction of loading, the length of the treatment period, microfracture of the alveolar bone, and overheating $[1,16,37,38]$.

Intraosseous heat generation can seriously interfere with the local homeostatic conditions of the bone. A temperature increase to $40^{\circ} \mathrm{C}$ initiates hyperemia; however, if the thermal elevation continues and reaches $53^{\circ} \mathrm{C}$, blood flow stops entirely [20,39]. Eriksson and colleagues reported that the threshold for thermal damage to osseous structures fell between 44 and $47^{\circ} \mathrm{C}[39,40]$. This means that for the measurements of our study, where the baseline temperature was a mean of $36^{\circ} \mathrm{C}$, safe temperature elevation fell between $\Delta \mathrm{t}=8-11^{\circ} \mathrm{C}$, depending on the exact baseline temperature of any given specimen. The results are interpreted accordingly. Drilling at $1200 \mathrm{rpm}$ without any irrigation resulted in a mean temperature elevation of $\Delta \mathrm{t}=7.76^{\circ} \mathrm{C}$, with elevations reaching $\Delta \mathrm{t}=11.5^{\circ} \mathrm{C}$, which is unacceptable in terms of safety. The apparently moderate mean temperature elevation of $\Delta \mathrm{t}=5.92^{\circ} \mathrm{C}$ for the $900 \mathrm{rpm} /$ no irrigation group might suggest that drilling at this speed without irrigation could be safe, but note that the maximum elevation in this group was still in the unsafe range $\left(\Delta \mathrm{t}=9.5^{\circ} \mathrm{C}\right)$. The mean temperature elevations without irrigation at $200 \mathrm{rpm}\left(\Delta \mathrm{t}=2.22^{\circ} \mathrm{C}\right)$ and $600 \mathrm{rpm}\left(\Delta \mathrm{t}=3.74{ }^{\circ} \mathrm{C}\right)$ remained in the safe range. Elevation maxima did not exceed the safety threshold either. This might give the impression that bone drilling without irrigation at low speeds is completely safe. Reality appears to be a bit more complicated. Iyer and co-workers concluded that a temperature elevation of only $4.3^{\circ} \mathrm{C}$ caused a significant difference in the quality of the newly formed bone around an implant [41]. In other words, it seems that thermal harm is not necessarily linked to extreme heat elevations: lower temperatures can do harm too but not immediately and not necessarily in the form of some necrotic process. This corroborates the repeated conclusion that intraosseous heat elevation is best kept as low as possible, which means that no bone drilling should happen without irrigation. While this conclusion is commonplace in implant dentistry done with implants of regular dimensions, less is known about the situation with mini-implants, which is exactly what motivated our study. From our data, it seems that this smaller system (i.e., drills of a smaller diameter and a shallower/narrower bony socket) is even more sensitive to heat generation (and the presence or absence of cooling), even at low speeds.

The effects of the use of cooled irrigation fluids in bone drilling are also relatively under investigated. The results of Isler et al. [42] suggest that the use of $4{ }^{\circ} \mathrm{C}$ saline might have a positive effect on bone healing. Sener and his colleagues [24] concluded that $10^{\circ} \mathrm{C}$ saline can be more effective at keeping temperatures under control in an implant preparation setting than $25^{\circ} \mathrm{C}$ saline, whereas Kondo et al. [43] demonstrated the superiority of cold irrigation fluid in minimizing temperature elevation in a neurosurgical setting, where strict temperature control is crucial to protect the nervous tissue. Our research group found that a $10{ }^{\circ} \mathrm{C}$ saline solution provides sufficient external cooling during normal implant site preparation with lower temperature increments as compared to room temperature $\left(20^{\circ} \mathrm{C}\right)$ irrigation $[33,35,36]$. As for the results of the present study, the use of both 10 and $20^{\circ} \mathrm{C}$ significantly reduced heat generation at all speeds. At any speed, there was a statistically significant difference in temperature elevation, depending on the temperature of the irrigation fluid (and compared to the no-irrigation condition), which corroborates our above conclusion about the sensitivity of the system.

The most important limitation of this study is its in vitro nature. Care was taken, though, that the key elements and parameters of the model (such as the cortical thickness of the bone and the axial load) are accepted in the literature. Furthermore, to our knowledge, this is the first study to examine multiple aspects of heat generation and control within the 
same model in connection with orthodontic anchorage and with a clinically relevant drill bit diameter $(\varnothing=1.4 \mathrm{~mm})$.

Another relative limitation is that the exact drilling time was not considered, while it obviously appears in the literature as a factor [21,44-47]. However, the results suggest that within the short timeframe we used (no drilling lasted more than $10 \mathrm{~s}$ ), time was not a clinically significant factor (there was only one instance in only one group when the temperature increment exceeded the generally accepted safety limit).

\section{Conclusions}

Based on the results and the relevant literature, and within the limitations of this study, we conclude that irrigation while preparing a pilot hole for a self-tapping orthodontic miniscrew is of utmost importance, even at low drilling speeds. In such cases, the working area is small, which, without proper irrigation, probably makes the system more susceptible to heat concentration than what can be observed during regular (i.e., prosthetic) implant surgery. As a general conclusion, it is recommendable that, when preparing the site for these miniscrews, the clinician should observe the "lowest possible speed with constant irrigation" principle known from implant dentistry. As for the temperature of the cooling fluid, this does influence local temperature elevation to a significant extent, but the difference does not seem to be relevant from a clinical point of view. However, it does not necessarily mean that it does not influence healing. This should be clarified in histological studies.

Author Contributions: Conceptualization, J.P., I.B., and E.S.; methodology J.P., I.B. and E.S.; software, G.B. and I.B.; validation, G.B. and I.B.; formal analysis, G.B. and I.B.; investigation, I.B.; resources I.B.; data curation, G.B. and I.B.; writing-original draft preparation, G.B., I.B. and E.S.; writing—review and editing, G.B., I.B., J.P. and E.S.; visualization, G.B. and I.B.; supervision, G.B., J.P. and E.S. All authors have read and agreed to the published version of the manuscript.

Funding: This research received no external funding.

Institutional Review Board Statement: Not applicable.

Informed Consent Statement: Not applicable.

Data Availability Statement: Not applicable.

Acknowledgments: The authors would like to thank PSM Medical Solutions Ltd. for their support of the drill bits. The authors would like to thank Nikolett Langó for her help during visualization of the article.

Conflicts of Interest: The authors declare no conflict of interest.

\section{References}

1. Papadopoulos, M.A.; Tarawneh, F. The use of miniscrew implants for temporary skeletal anchorage in orthodontics: A comprehensive review. Oral Surg. Oral Med. Oral Pathol. Oral Radiol. Endod. 2007, 103, e6-e15. [CrossRef]

2. Tsui, W.K.; Chua, H.D.; Cheung, L.K. Bone anchor systems for orthodontic application: A systematic review. Int. J. Oral Maxillofac. Surg. 2012, 41, 1427-1438. [CrossRef]

3. Afrashtehfar, K.I.; Del Fabbro, M. Clinical performance of zirconia implants: A meta-review. J. Prosthet. Dent. 2020, 123, 419-426. [CrossRef]

4. Lyu, X.; Guo, J.; Chen, L.; Gao, Y.; Liu, L.; Pu, L.; Lai, W.; Long, H. Assessment of available sites for palatal orthodontic mini-implants through cone-beam computed tomography. Angle Orthod 2020, 90, 516-523. [CrossRef] [PubMed]

5. Kanomi, R. Mini-implant for orthodontic anchorage. J. Clin. Orthod. 1997, 31, 763-767.

6. Reichow, A.M.; Melo, A.C.; de Souza, C.M.; Castilhos, B.B.; Olandoski, M.; Alvim-Pereira, C.C.; Alvim-Pereira, F.; Trevilatto, P.C. Outcome of orthodontic mini-implant loss in relation to interleukin 6 polymorphisms. Int. J. Oral Maxillofac. Surg. 2016, 45, 649-657. [CrossRef] [PubMed]

7. Wilmes, B.; Drescher, D. Impact of bone quality, implant type, and implantation site preparation on insertion torques of mini-implants used for orthodontic anchorage. Int. J. Oral Maxillofac. Surg. 2011, 40, 697-703. [CrossRef] [PubMed]

8. Afrashtehfar, K.I. Patient and miniscrew implant factors influence the success of orthodontic miniscrew implants. Evid. Based Dent. 2016, 17, 109-110. [CrossRef] 
9. Tachibana, R.; Motoyoshi, M.; Shinohara, A.; Shigeeda, T.; Shimizu, N. Safe placement techniques for self-drilling orthodontic mini-implants. Int. J. Oral Maxillofac. Surg. 2012, 41, 1439-1444. [CrossRef]

10. Wilmes, B.; Rademacher, C.; Olthoff, G.; Drescher, D. Parameters affecting primary stability of orthodontic mini-implants. J. Orofac. Orthop. Fortschr. Kieferorthopadie 2006, 67, 162-174. [CrossRef]

11. Kuroda, S.; Sugawara, Y.; Deguchi, T.; Kyung, H.M.; Takano-Yamamoto, T. Clinical use of miniscrew implants as orthodontic anchorage: Success rates and postoperative discomfort. Am. J. Orthod. Dentofac. Orthop. 2007, 131, 9-15. [CrossRef]

12. Uemura, M.; Motoyoshi, M.; Yano, S.; Sakaguchi, M.; Igarashi, Y.; Shimizu, N. Orthodontic mini-implant stability and the ratio of pilot hole implant diameter. Eur. J. Orthod. 2012, 34, 52-56. [CrossRef]

13. Motoyoshi, M.; Hirabayashi, M.; Uemura, M.; Shimizu, N. Recommended placement torque when tightening an orthodontic mini-implant. Clin. Oral Implant. Res. 2006, 17, 109-114. [CrossRef]

14. Matsuoka, M.; Motoyoshi, M.; Sakaguchi, M.; Shinohara, A.; Shigeede, T.; Saito, Y.; Matsuda, M.; Shimizu, N. Friction heat during self-drilling of an orthodontic miniscrew. Int. J. Oral Maxillofac. Surg. 2011, 40, 191-194. [CrossRef] [PubMed]

15. Cheng, S.J.; Tseng, I.Y.; Lee, J.J.; Kok, S.H. A prospective study of the risk factors associated with failure of mini-implants used for orthodontic anchorage. Int. J. Oral Maxillofac. Implant. 2004, 19, 100-106.

16. Park, H.S.; Jeong, S.H.; Kwon, O.W. Factors affecting the clinical success of screw implants used as orthodontic anchorage. Am. J. Orthod. Dentofac. Orthop. 2006, 130, 18-25. [CrossRef] [PubMed]

17. Wu, T.Y.; Kuang, S.H.; Wu, C.H. Factors associated with the stability of mini-implants for orthodontic anchorage: A study of 414 samples in Taiwan. J. Oral Maxillofac. Surg. 2009, 67, 1595-1599. [CrossRef]

18. Gurdan, Z.; Vajta, L.; Toth, A.; Lempel, E.; Joob-Fancsaly, A.; Szalma, J. Effect of pre-drilling on intraosseous temperature during self-drilling mini-implant placement in a porcine mandible model. J. Oral Sci. 2017, 59, 47-53. [CrossRef] [PubMed]

19. Abouzgia, M.B.; James, D.F. Temperature rise during drilling through bone. Int. J. Oral Maxillofac. Implant. 1997, 12, $342-353$.

20. Eriksson, R.A.; Albrektsson, T. The effect of heat on bone regeneration: An experimental study in the rabbit using the bone growth chamber. J. Oral Maxillofac. Surg. 1984, 42, 705-711. [CrossRef]

21. Mohlhenrich, S.C.; Modabber, A.; Steiner, T.; Mitchell, D.A.; Holzle, F. Heat generation and drill wear during dental implant site preparation: Systematic review. Br. J. Oral Maxillofac. Surg. 2015, 53, 679-689. [CrossRef]

22. Quaranta, A.; Andreana, S.; Spazzafumo, L.; Piemontese, M. An in vitro evaluation of heat production during osteotomy preparation for dental implants with compressive osteotomes. Implant Dent. 2013, 22, 161-164. [CrossRef] [PubMed]

23. Kim, H.J.; Yun, H.S.; Park, H.D.; Kim, D.H.; Park, Y.C. Soft-tissue and cortical-bone thickness at orthodontic implant sites. Am. J. Orthod. Dentofac. Orthop. 2006, 130, 177-182. [CrossRef] [PubMed]

24. Sener, B.C.; Dergin, G.; Gursoy, B.; Kelesoglu, E.; Slih, I. Effects of irrigation temperature on heat control in vitro at different drilling depths. Clin. Oral Implant. Res. 2009, 20, 294-298. [CrossRef]

25. Stelzle, F.; Frenkel, C.; Riemann, M.; Knipfer, C.; Stockmann, P.; Nkenke, E. The effect of load on heat production, thermal effects and expenditure of time during implant site preparation-An experimental ex vivo comparison between piezosurgery and conventional drilling. Clin. Oral Implant. Res. 2014, 25, e140-e148. [CrossRef] [PubMed]

26. Augustin, G.; Davila, S.; Udiljak, T.; Vedrina, D.S.; Bagatin, D. Determination of spatial distribution of increase in bone temperature during drilling by infrared thermography: Preliminary report. Arch. Orthop. Trauma Surg. 2009, 129, 703-709. [CrossRef] [PubMed]

27. Sedlin, E.D.; Hirsch, C. Factors affecting the determination of the physical properties of femoral cortical bone. Acta Orthop. Scand. 1966, 37, 29-48. [CrossRef] [PubMed]

28. Nam, O.; Yu, W.; Choi, M.Y.; Kyung, H.M. Monitoring of Bone Temperature During Osseous Preparation for Orthodontic Micro-Screw Implants: Effect of Motor Speed and Ressure. Key Eng. Mater. 2006, 321-323, 1044-1047. [CrossRef]

29. Wilmes, B.; Ottenstreuer, S.; Su, Y.Y.; Drescher, D. Impact of implant design on primary stability of orthodontic mini-implants. J. Orofac. Orthop. Fortschr. Kieferorthopadie 2008, 69, 42-50. [CrossRef] [PubMed]

30. Mishra, S.K.; Chowdhary, R. Heat generated by dental implant drills during osteotomy-a review: Heat generated by dental implant drills. J. Indian Prosthodont. Soc. 2014, 14, 131-143. [CrossRef] [PubMed]

31. Tehemar, S.H. Factors affecting heat generation during implant site preparation: A review of biologic observations and future considerations. Int. J. Oral Maxillofac. Implant. 1999, 14, 127-136.

32. Pandey, R.K.; Panda, S.S. Drilling of bone: A comprehensive review. J. Clin. Orthop. Trauma 2013, 4, 15-30. [CrossRef]

33. Barrak, I.; Boa, K.; Joob-Fancsaly, A.; Varga, E.; Sculean, A.; Piffko, J. Heat Generation During Guided and Freehand Implant Site Preparation at Drilling Speeds of 1500 and 2000 RPM at Different Irrigation Temperatures: An In Vitro Study. Oral Health Prev. Dent. 2019, 17, 309-316. [CrossRef] [PubMed]

34. Barrak, I.; Joob-Fancsaly, A.; Braunitzer, G.; Varga, E., Jr.; Boa, K.; Piffko, J. Intraosseous Heat Generation During Osteotomy Performed Freehand and Through Template With an Integrated Metal Guide Sleeve: An In Vitro Study. Implant Dent. 2018, 27, 342-350. [CrossRef] [PubMed]

35. Barrak, I.; Joob-Fancsaly, A.; Varga, E.; Boa, K.; Piffko, J. Effect of the Combination of Low-Speed Drilling and Cooled Irrigation Fluid on Intraosseous Heat Generation During Guided Surgical Implant Site Preparation: An In Vitro Study. Implant Dent. 2017, 26, 541-546. [CrossRef] 
36. Boa, K.; Barrak, I.; Varga, E., Jr.; Joob-Fancsaly, A.; Varga, E.; Piffko, J. Intraosseous generation of heat during guided surgical drilling: An ex vivo study of the effect of the temperature of the irrigating fluid. Br. J. Oral Maxillofac. Surg. 2016, 54, 904-908. [CrossRef]

37. Papageorgiou, S.N.; Zogakis, I.P.; Papadopoulos, M.A. Failure rates and associated risk factors of orthodontic miniscrew implants: A meta-analysis. Am. J. Orthod. Dentofac. Orthop. 2012, 142, 577-595 e577. [CrossRef]

38. Inoue, M.; Kuroda, S.; Yasue, A.; Horiuchi, S.; Kyung, H.M.; Tanaka, E. Torque ratio as a predictable factor on primary stability of orthodontic miniscrew implants. Implant Dent. 2014, 23, 576-581. [CrossRef]

39. Eriksson, A.R.; Albrektsson, T. Temperature threshold levels for heat-induced bone tissue injury: A vital-microscopic study in the rabbit. J. Prosthet. Dent. 1983, 50, 101-107. [CrossRef]

40. Eriksson, A.R.; Albrektsson, T.; Albrektsson, B. Heat caused by drilling cortical bone. Temperature measured in vivo in patients and animals. Acta Orthop. Scand. 1984, 55, 629-631. [CrossRef]

41. Iyer, S.; Weiss, C.; Mehta, A. Effects of drill speed on heat production and the rate and quality of bone formation in dental implant osteotomies. Part II: Relationship between drill speed and healing. Int. J. Prosthodont. 1997, 10, 536-540. [PubMed]

42. Isler, S.C.; Cansiz, E.; Tanyel, C.; Soluk, M.; Selvi, F.; Cebi, Z. The effect of irrigation temperature on bone healing. Int. J. Med. Sci. 2011, 8, 704-708. [CrossRef] [PubMed]

43. Kondo, S.; Okada, Y.; Iseki, H.; Hori, T.; Takakura, K.; Kobayashi, A.; Nagata, H. Thermological study of drilling bone tissue with a high-speed drill. Neurosurgery 2000, 46, 1162-1168. [CrossRef] [PubMed]

44. Ginta, T.; Ariwahjoedi, B. Cutting Force and Temperature Variation in Bone Drilling-A Review. Adv. Mater. Res. 2014, 845, 934-938. [CrossRef]

45. Ben Achour, A.; Petto, C.; Meissner, H.; Hipp, D.; Nestler, A.; Lauer, G.; Teicher, U. The Influence of Thrust Force on the Vitality of Bone Chips Harvested for Autologous Augmentation during Dental Implantation. Materials 2019, 12, 3695. [CrossRef]

46. Teicher, U.; Ben Achour, A.; Nestler, A.; Brosius, A.; Lauer, G. Process based analysis of manually controlled drilling processes for bone. AIP Conf. Proc. 2018, 1960, 070025. [CrossRef]

47. Pellicer-Chover, H.; Penarrocha-Oltra, D.; Aloy-Prosper, A.; Sanchis-Gonzalez, J.C.; Penarrocha-Diago, M.A.; Penarrocha-Diago, M. Comparison of peri-implant bone loss between conventional drilling with irrigation versus low-speed drilling without irrigation. Med. Oral Patol. Oral Cir. Bucal 2017, 22, e730-e736. [CrossRef] 